\title{
Concentrations of Sodium, Potassium, Copper, Zinc and Heavy Metals in Camel Milk Reared Under Pasture and Farm Conditions in South Egypt Damarany, A. I. \\ Department of Animal and Poultry Production, Faculty of Agriculture and Natural Resources, Aswan University, Egypt.
}

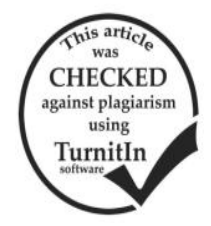

ABSTRACT

The present study aimed to determine concentration of sodium, potassium, copper, zinc, lead and cadmium in camel's milk. The camels was divided into two groups, the first group reared under the traditional farms and the second reared under pasture system. The elements were determined by using atomic absorption (AA) flame spectrometry techniques. The results indicated that the overall mean of sodium and potassium contents in camel milk was $1848.54 \pm 571.2$ and $3749.90 \pm 328.9 \mathrm{mg} / \mathrm{l}$, respectively. While, the overall mean of copper and zinc contents in camel milk was $0.065 \pm 0.02$ and $0.20 \pm 0.06 \mathrm{mg} / \mathrm{l}$, respectively. The overall mean of lead and cadmium contents in milk camel was $1.56 \pm 0.85$ and $0.008 \pm 0.001 \mathrm{mg} / 1$, respectively. Sodium content in pasture camel milk was lower $(1823.59 \pm 572.7 \mathrm{mg} / \mathrm{l})$ than farm $(1873.49 \pm 578.03 \mathrm{mg} / \mathrm{l})$, but the content of potassium was higher $(3868.49 \pm 162.75 \mathrm{mg} / \mathrm{l})$ in farm than pasture milk $(3631.32 \pm 411.52 \mathrm{mg} / \mathrm{l})$. Content of copper in pasture milk was higher $(0.07 \pm 0.02 \mathrm{mg} / \mathrm{l})$ than the farm milk $(0.06 \pm 0.02 \mathrm{mg} / \mathrm{l})$. Similar trend was observed in zinc content in pasture milk was higher $(0.21 \pm 0.07 \mathrm{mg} / \mathrm{l})$ than the farm milk $(0.19 \pm 0.03 \mathrm{mg} / \mathrm{l})$. Lead content was equal in pasture and the farm milk $(1.54 \pm 1.1$ and $1.58 \pm 0.45 \mathrm{mg} / \mathrm{l}$, respectively). Cadmium content in pasture milk was higher $(0.016 \pm 0.001 \mathrm{mg} / \mathrm{l})$ than the farm milk $(0.0005 \pm 0.0001 \mathrm{mg} / \mathrm{l})$. The present results of this study indicated that marked differences in concentration of $\mathrm{K}$ and $\mathrm{Cd}$ between pasture of milk and farm milk.

Keywords: $\mathrm{Na}, \mathrm{K}, \mathrm{Cu}, \mathrm{Zn}$, heavy metals, milk, camels

\section{INTRODUCTION}

Camel milk is used in hot and arid regions as an essential nutritional source, for high energy and vitamins contents (Gorakh et al., 2000 and Al-Awadi and Srikumar, 2001). Camel milk, use as medicinal, dietary properties and used as a fresh milk in some countries (Faye et al., 2008 and Meldebekova et al., 2008). These properties are widely exploited for human health (Kenzhebulat et al. 2000 ). Camel milk is considered as anti-cancer (Magjeed, 2005) and antidiabetic properties (Agrawal et al., 2003 and Agrawal et al., 2005). Camel milk content of vitamin C lactoferrin, and immunoglobulin (El-Agamy et al., 1996 and Konuspayeva et al., 2007) can act as nutritional supplement in tuberculosis patients (Mal et al., 2000). EL-Fakharany et al. (2012) reported direct interaction between hepatitis $\mathrm{C}$ virus (HCV) and camel IgGs and camel lactoferrin (cLf), in addition to previous camels milk is well tolerated by lactase-deficient children who are allergic to cow milk ( El- Agamy et al., 2009) and viral and bacterial infections (El- Agamy et al., 1992). In the light of the previous facts till now some recently investigations estimate the content of minerals in camel milk (Al-Wabel, 2008, Konuspayeva et al., 2009 and El-bagermi et al., 2014). Little investigations about the content of minerals in milk of camels reared in farms and pasture under conditions of south Egypt, therefore, the present study aimed to quantify of sodium, potassium, copper, zinc, lead and cadmium in camel's milk reared in farms and pasture under conditions of south Egypt.

\section{MATERIALS AND METHODS Location}

This study was carried out in Aswan governorate south Egypt. The farm camels located in Kom Ombou city ( $32^{\circ}, 31^{\prime} 23^{\prime \prime}$ East and 22, 28' 09" North) near by industrial district (sugar factory) and the pasture camels was located in Shalateen area near by Mines search of the gold (contamination resources). The experimental period was continued for three months from September to December, 2015.

\section{Management and feeding system:}

Females camels were divided into two comparable groups. The first group $(n=60)$ was kept in traditional semi shading farm and fed on concentrate mixture (corn grain and wheat bran), wheat straw, fresh alfa-alfa and alfa-alfa hay. Whereas, the second group $(n=60)$ was raised under pasture conditions. All females camels fed ad-libitum and reared under traditional conditions.

\section{Determination of elements:}

According to AOAC (2000) as a chemical method, milk samples $(n=120)$ were analyzed quantitatively for determination sodium $(\mathrm{Na})$, potassium $(\mathrm{K})$, copper $(\mathrm{Cu})$, zinc $(\mathrm{Zn})$, lead $(\mathrm{Pb})$ and cadmium (Cd) using atomic absorption (AA) flame spectrometry techniques. Spectrometer: (ICE 3000C113500040 v1.30, England) was used at wave length $589.0 \mathrm{~nm}$ for $(\mathrm{Na}), 766.5 \mathrm{~nm}(\mathrm{~K}), 324.8 \mathrm{~nm}(\mathrm{Cu}), 213.9(\mathrm{Zn}), 217.0$ $(\mathrm{Pb})$ and $228.8(\mathrm{Cd})$. Measurement mode: Absorbance, Band pass: of $\mathrm{Na}, \mathrm{K}, \mathrm{Cu}, \mathrm{Pb}$ and $\mathrm{Cd}$ was $(0.5 \mathrm{~nm})$, but for $\mathrm{Zn}$ was (0.2). Fuel Flow: $1.1 \mathrm{~L} / \mathrm{min}$ for $\mathrm{Na}, \mathrm{K}, \mathrm{Cu}$ and $\mathrm{Pb}$ while $\mathrm{Cd}$ and $\mathrm{Zn}$ was $1.2 \mathrm{~L} / \mathrm{min}$. Analysis of copper, zinc, lead and cadmium metals in animal's diet $(\mathrm{mg} / \mathrm{kg})$ and drinking water $(\mathrm{mg} / \mathrm{l})$ are shown in Table (1).

\section{Procedures of analysis:}

The milk samples $(5 \mathrm{ml})$ were analyzed in Unit of Environmental Studies and Development, Aswan University, according to the procedures descript by AOAC (2000) for protein digestion and extraction. 1.0 $\mathrm{ml}$ of the milk sample was measured into a clean $250 \mathrm{ml}$ dry Pyrex digestion flask. $3.0 \mathrm{ml}$ of $65 \%$ nitric acid was added, followed by the addition of $3.0 \mathrm{ml}$ of $30 \%$ hydrogen peroxide. The digestion flask was heated gently until frothing subsided. The sample was then 
heated to dryness, dissolved in $30 \mathrm{ml}$ deionized distilled water and filtered with Whatman filter paper 102, $12.5 \mathrm{~cm}$. The solution was made up to volume in a $50 \mathrm{ml}$ flask and stored in a special container ready for analysis.

Table 1. Concentrations ( $X \pm S E$ ) of copper, zinc, lead and cadmium elements in the experimental animal diet $(\mathrm{mg} / \mathrm{kg})$ and drinking water $(\mathrm{mg} / \mathrm{l})$

\begin{tabular}{|c|c|c|c|}
\hline Minerals & $\begin{array}{c}\mathrm{NRC}^{*} \\
\text { requirement }\end{array}$ & Pasture & Farms \\
\hline \multicolumn{4}{|c|}{ Mineral in animal diet } \\
\hline Copper & $7-11$ & $3.6 \pm 0.3$ & $4.5 \pm 0.6$ \\
\hline Zinc & 32.0 & $65.4 \pm 1.4$ & $73.7 \pm 2.1$ \\
\hline Lead & 0.2 & $0.5 \pm 0.1$ & $0.3 \pm 0.03$ \\
\hline Cadmium & 0.5 & $0.8 \pm 0.02$ & $0.6 \pm 0.04$ \\
\hline \multicolumn{4}{|c|}{ Mineral in drinking water } \\
\hline Copper & 0.5 & $0.5 \pm 0.1$ & $0.3 \pm 0.1$ \\
\hline Zinc & 25.0 & $0.7 \pm 0.1$ & $0.5 \pm 0.1$ \\
\hline Lead & 0.015 & $0.15 \pm 0.02$ & $0.08 \pm 0.04$ \\
\hline Cadmium & 0.005 & $0.009 \pm 0.001$ & $0.007 \pm 0.002$ \\
\hline
\end{tabular}

*Source: NRC, 2001

Number of samples for each group was 4.

Statistical analysis:

The model included one fixed factor, system of feeding. The significance among the means was checked using T. test (SAS, 2002). The used model was: $\mathrm{Yij}=\mu+\mathrm{Fi}+\mathrm{eij}$

Where:

$\mathrm{Yij}_{\mathrm{ij}}=$ the observations trait

$\mu=$ overall mean

$\mathrm{Fi}=$ effect of rearing conditions (the farm $=1$, the pasture $=2$ ) $\mathrm{eij}=$ experimental error assumed to be randomly distributed $\left(0, \partial^{2}\right)$

\section{RESULTS AND DISCUSSION}

\section{Concentrations of sodium and potassium in pasture} and farm camel milks:

The overall mean of sodium and potassium in camel milk of pasture and farms was $1848.54 \pm 571.2$ and $3749.90 \pm 328.9 \mathrm{mg} / \mathrm{l}$, respectively (Table 1). These results were higher than that reported by Soliman (2005); Amin et al. (2008) and Shamsia (2009) who found that concentrations of sodium and potassium in camel milk were ranged $(570-748 \mathrm{mg} / \mathrm{kg})$ and $(972-$ $1790 \mathrm{mg} / \mathrm{kg}$ ) respectively. Higher concentrations of sodium and potassium in camel milk that observed in the present study may be due to nutrition. The results indicated that concentration of sodium in milk farm was higher $(1873.49 \pm 578.03 \mathrm{mg} / \mathrm{l})$ than pasture camels $(1823.59 \pm 572.7 \mathrm{mg} / \mathrm{l})$, but the difference was not significant $(\mathrm{P}<0.05)$, while the content of potassium in farm milk was significantly $(\mathrm{P}<0.05)$ higher $(3868.49 \pm$ $162.75 \mathrm{mg} / \mathrm{l})$ than pasture milk $(3631.32 \pm 411.52 \mathrm{mg} / \mathrm{l})$. The significant difference of potassium in pasture and farm milk may be due to the difference of nutrition and grazing may be lead to lost a lot of minerals during sweating. The present results agree with that reported by Alwan et al. (2014), who found that concentration of sodium and potassium in Farm-reared and Desert-reared Libyan Maghrebi Camels' Milk was 43.14 \pm 9.77 ,
$148.1 \pm 8.8$ and $69.26 \pm 1.1, \quad 154.57 \pm 5.5 \quad \mathrm{mg} / \mathrm{kg}$, respectively. However, the obtained concentration of sodium and potassium in camel milk was higher $(1848.54 \pm 571.2$ and $3749.90 \pm 328.9 \mathrm{mg} / \mathrm{l})$ than that reported by Nnadozie et al. (2014) who found concentration of sodium and potassium in camel milk was $110.0 \pm 2.5$ and $1133.77 \pm 5.64 \mathrm{mg} / \mathrm{kg}$ in Nigeria. Also, lower concentration were reported by Al-Wabel (2008), who found that the concentration of sodium and potassium in camel milk was $115.87 \pm 4.99$ and $133.77 \pm 5.64 \mathrm{mg} / \mathrm{kg}$ in the central region of Saudi Arabia. Finally, lower concentration of potassium in camel milk $(571.0 \pm 0.81 \mathrm{mg} / \mathrm{l})$ was reported by ElBagermi et al. (2014).

Table 1. Mean $\pm \mathrm{SE}$ of sodium and potassium (mg/l ) in camel milk under pasture and farm conditions

\begin{tabular}{llll}
\hline Element & $\begin{array}{l}\text { Pasture } \\
\text { camels }\end{array}$ & $\begin{array}{l}\text { Farm } \\
\text { camels }\end{array}$ & $\begin{array}{l}\text { Overall } \\
\text { mean }\end{array}$ \\
\hline $\mathrm{Na}$ & $1823.59 \pm$ & $1873.49 \pm$ & $1848.54 \pm$ \\
$(\mathrm{mg} / \mathrm{l})$ & 572.7 & 578.03 & 571.2 \\
$\mathrm{~K}$ & $3631.32 \pm$ & $3868.49 \pm$ & $3749.90 \pm$ \\
$(\mathrm{mg} / \mathrm{l})$ & $411.52^{\mathbf{b}}$ & $162.75^{\mathbf{a}}$ & 328.9 \\
\hline
\end{tabular}

${ }^{\mathrm{a}, \mathrm{b}}$ : values within the same row having different superscripts are different at $\mathrm{P}<\mathbf{0 . 0 5}$.

Concentrations of copper and zinc in pasture and farms camel milks:

The overall mean of copper and zinc concentration in pasture and farm milk was $0.065 \pm 0.02$ and $0.20 \pm 0.06 \mathrm{mg} / \mathrm{l}$, respectively (Table 2). These results were lower than that reported by Soliman (2005); Amin et al. (2008) and Shamsia (2009) who found that concentrations of copper and zinc concentration in camel milk were ranged $(0.6-1.9 \mathrm{mg} / \mathrm{kg})$ and $(1.9-9.2$ $\mathrm{mg} / \mathrm{kg}$ ) respectively. Lower content of copper and zinc concentration in camel milk that showed in the present study may be due to low content in the forage and deficiency of eatable. These results indicated that no significant difference of copper concentration in farm $(0.06 \pm 0.02 \mathrm{mg} / \mathrm{l})$ and pasture $(0.07 \pm 0.02 \mathrm{mg} / \mathrm{l}) \mathrm{milk}$. Similar trend was observed of zinc concentration in booth milk (Table 2). The present result is closed to that reported by Meldebekova et al. (2008) and El-Bagermi et al. (2014), who found that the concentration of copper in camel milk was $0.065 \pm 0.04$ and $0.08 \pm 0.05$ $\mathrm{mg} / \mathrm{l}$, respectively. Similar trend was reported by Alwan et al. (2014), who found that concentration of copper and zinc in Farm-reared and Desert-reared Libyan Maghrebi Camels' Milk was $0.58 \pm 0.052,0.24 \pm 0.27$ and $0.42 \pm 0.02,0.14 \pm 0.02 \mathrm{mg} / \mathrm{kg}$, respectively. However, the obtained result was lower than that reported by Nnadozie et al. (2014) and Saini et al. (2007), who found the concentration of copper and zinc in camel milk was $0.161,0.156$ and $0.416 \mathrm{mg} / \mathrm{kg}$, respectively, while the concentration of zinc was higher $0.20 \pm 0.06$ than that reported by Saini et al. (2007) who found that concentration of zinc in camel milk was $0.071 \pm 0.07$ ppm. 
Table 2. Mean \pm SE of copper and zinc (mg/l ) in camel milk under pasture and farm conditions

\begin{tabular}{lccc}
\hline Element & $\begin{array}{c}\text { Pasture } \\
\text { camels }\end{array}$ & $\begin{array}{c}\text { Farms } \\
\text { camels }\end{array}$ & Overall mean \\
\hline $\mathrm{Cu}(\mathrm{mg} / \mathrm{l})$ & $0.07 \pm 0.02$ & $0.06 \pm 0.02$ & $0.065 \pm 0.02$ \\
$\mathrm{Zn}(\mathrm{mg} / \mathrm{l})$ & $0.21 \pm 0.07$ & $0.19 \pm 0.03$ & $0.20 \pm 0.06$ \\
\hline
\end{tabular}

\section{Concentrations of lead and cadmium in pasture and} farm camel milks:

The overall mean of lead and cadmium concentration in pasture and farm milks was $1.56 \pm 0.85$ and $0.008 \pm$ $0.001 \mathrm{mg} / \mathrm{l}$, respectively (Table 3 ). The obtained results were agree with that reported by Amin et al. (2008) who found that concentration of lead and cadmium camel milk was 0.016 and $1.35 \mathrm{mg} / \mathrm{kg}$ respectively. These results indicated that no difference in content of lead in pasture and farms milks (Table 3), but the concentration of cadmium was higher $(0.016 \pm 0.001 \mathrm{mg} / \mathrm{l})$ in pasture milk than in farms milk $(0.0005 \pm 0.0001 \mathrm{mg} / \mathrm{l})$ (Table 3 ). The significant difference of cadmium in pasture and farm milk may be due to the concentration of element in the forges. Concentration of lead in camel milk was higher $(1.56 \pm 0.85 \mathrm{mg} / \mathrm{l})$ than that reported by (Saini et al., 2007; Meldebekova et al., 2008 and El-Bagermi et al., 2014), who found content that of lead in camel milk ranged between 0.022 and $0.025 \mathrm{mg} / \mathrm{l}$. The overall concentration of lead in camel milk was higher than that allowed $(1.0 \mathrm{ppm})$ in Egyptian food according to E.E.A.A (1994). Concentration of cadmium in camel milk was lower $(0.008 \pm 0.001 \mathrm{mg} / \mathrm{l})$ than that reported by Nnadozie et al. (2014) and El-Bagermi et al. (2014) (0.09 and $0.105 \mathrm{ppm})$. While concentration of cadmium in camel milk was lower than that allowed $0.5 \mathrm{ppm}$ in Egyptian food according to E.E.A.A (1994). The World Health Organization (WHO, 1992) has established a provisional tolerable weekly intake (PTWI) of cadmium was $0.007 \mathrm{mg} / \mathrm{kg}$ body weight of human. Provisional tolerable weekly intake (PTW) value correspond to a daily tolerable intake level was $0.07 \mathrm{mg} / \mathrm{kg}$ of cadmium for the average $70-\mathrm{kg}$ man and $0.060 \mathrm{mg} / \mathrm{kg}$ of cadmium per day for the average $60-\mathrm{kg}$ woman. However, provisional tolerable weekly intake (PTWI) of lead was $0.025 \mathrm{mg} / \mathrm{kg}$ body weight of human (WHO, 2004).

Table 3: Mean $\pm \mathrm{SE}$ of lead and cadmium (mg/l ) in camel milk under pasture and farm conditions

\begin{tabular}{lccc}
\hline Element & $\begin{array}{c}\text { Pasture } \\
\text { camels }\end{array}$ & $\begin{array}{c}\text { Farms } \\
\text { camels }\end{array}$ & Overall mean \\
\hline $\mathrm{Pb}(\mathrm{mg} / \mathrm{l})$ & $1.54 \pm 1.1$ & $1.58 \pm 0.45$ & $1.56 \pm 0.85$ \\
$\mathrm{Cd}(\mathrm{mg} / \mathrm{l})$ & $0.016 \pm$ & $0.0005 \pm$ & $0.008 \pm 0.001$ \\
& $0.001^{\mathrm{a}}$ & $0.0001^{\mathrm{b}}$ & \\
$\mathrm{a}, \overline{\mathrm{b}}$ val
\end{tabular}

${ }^{\mathrm{a}, \mathrm{b}}$ : values within the same row having different superscripts are different at $\mathrm{P}<\mathbf{0 . 0 5}$.

\section{CONCLUSION}

The present results of this study indicated that marked differences in content of $\mathrm{K}$ (macro-element) and
Cd (micro-element) between pasture of milk and farm milk.

\section{REFERENCES}

Agrawal, P. P; S.C. Swami; R. Beniwal; D.K. Kochar; M.S. Sahani; F.C. Tuteja and S.K. Ghouri (2003). Effect of raw camel milk on glycemic control, risk factors and diabetes quality of life in type-1 diabetes: a randomised prospective controlled study. Journal of Camel Practice and Research 10(1): 45-50.

Agrawal, P. P.; R. Beniwal, S. Sharma; D. K. Kochar; F.C. Tuteja; S.K. Ghorui; and M. S. Sahani (2005). Effect of raw camel milk in type 1 diabetic patients: 1 year randomized study. Journal of Camel Practice and Research, 12 (1):27-31.

Al-Awadi, F. M. and T. S. Srikumar (2001). Trace elements and their distribution in protein fractions of camel milk in comparison to other commonly consumed milks. Journal of Dairy Research, 68:463-469.

Al-Hashem, F. M. Dallak; N. Bashir; M. Elessa; R. M. Khalil and M. Al-Khateeb (2009). Camel's milk protects against cadmium chloride induced toxicity in white albino rats. American. Journal of Pharmacology and Toxicology. 4:107-117.

Al-Wabel, N. A.( 2008). Mineral contents of milk of cattle, camels, goats and sheep in the central region of Saudi Arabia. Asian Journal of Biochemistry, 3:373-375.

Alwan, O. A.; A. O. Igwegbe and A. A. Ahmad (2014). Effects of rearing conditions on the proximate composition of Libyan Maghrebi camels (Camelus dromedaries) milk. International Journal of Engineering and Applied Sciences, 4 (8): 1-6.

Amin, T. M.; M. K. Ibrahim; M. O. Abou El Nile and T. $\mathrm{H}$ Esmail (2008) Evaluation of Chemical Quality of Camel's and Cow's Milk With Special Reference to Some Heavy Metals Residues Bulletin of High Institute of Public Health, 38 (1): 168- 187.

AOAC (2000). Official Methods of Analysis. $17^{\text {th }}$ Edition. Gaithersburg, Maryland, USA.

E.E.A.A. (1994). Egyptian Environmental Affair Agency, Cairo, Egypt. Environmental Protection Law No. 4.

El-Agamy, E. I.; R. A., Ismail; C. P. Champagne and R. Assaf (1992). Antibacterial and antiviral activity of camel milk protective proteins. Journal of Dairy Research, 59:169-175.

El-Agamy, E. I.; R. A. Ismail; C. P. Champagne and R. Assaf (1996). Purification and characterization of lactoferrin, lactoperoxydase, lysozyme and immunoglobulins from camel's milk. International Dairy Journal, 6: 129-45. 
El-Agamy, E. I.; M. Nawar S.M. Shamsia; S. Awad and G. F. Haenlein ( 2009). Are camel milk proteins convenient to the nutrition of cow milk allergic children. Small Ruminant Research, 82:1-6.

El-Bagermi, M.A.;H.G. Edwards and A.I. Alajtal (2014). A Comparative Study on the Physicochemical Parameters and Trace Elements in Raw Milk Samples Collected from MisurataLibya. SOP Transactions on Analytical Chemistry, 1 (2):15-23.

EL-Fakharany, E. M.; N. Abedelbaky; B.M. Haroun; L. Sanchez, N. A. Redwan and E. M. Redwan (2012). Anti-infectivity of camel polyclonal antibodies against hepatitis $\mathrm{C}$ virus in Huh7.5 hepatoma. Virology Journal. 9: 201.

Faye, B.; G. Konuspayeva; S. Messad and G.Loiseau ( 2008). Discriminant milk components of Bactrian camel (Camelus bactrianus), dromedary (Camelus dromedarius) and hybrids. Dairy Science Technology, 88: 607-17.

Gorakh, M. D.; D.C. Sena; V.K. Jain and M.S. Sahani (2000). Therapeutic utility of camel milk as nutritional supplement against multiple drug resistant patients. In: Proc $2^{\text {nd }}$ Intl Camelid Conf Agro-economics of Camelid Farming. Almaty, Kazakhstan, 9:99.

Kenzhebulat, S.; B. Ermuhan and A. Tleuov ( 2000). Composition of camel milk and it's use in the treatment of infectious diseases in human. In " 2 nd Camelid Conf. Agroeconomics of Camelid Farming", AgroMerkur Publ., Almaty, Kazakhstan, 8-12 $2^{\text {th }}$ september, pp 101 .

Konuspayeva, G.; B. Faye; G. Loiseau; E. Diacono and S. Akhmetsadykova ( 2009). Pollution of Camel Milk by Heavy Metals in Kazakhstan. Environmental Pollution and Toxicology Journal, 1, 112-118.

Konuspayeva, G.; B. Faye; G. Loiseau and D. Levieux ( 2007). Lactoferrin and Immunoglobin content in camel milk from Kazakhstan. Journal of Dairy Science, 90: 38-46.
Magjeed, N. A. (2005). Corrective effect of milk camel on some cancer biomarkers in blood of rats intoxicated with aflatoxin B1. Journal of Saudi Chemistry. Soc., 9: 253-630.

Mal, G.; D.S. Sena; V. K. Jain; N.M. Singhvi and M. S. Sahani (2000). Role of camel milk as an adjuvant nutritional supplement in human tuberculosis patients. Livestock International 4(4): 7-14.

Meldebekova, A.; E. Diacono; G. Konuspayeva and B. Faye ( 2008). Heavy Metals and trace elements content in camel milk and shubat from Kazakhstan," In: B. Faye and Y. Sinyavskiy, Eds., Impact of Pollution on Animal Products, Springer Sciences, Dordrecht, The Netherland, pp. 117-123.

Nnadozie, C. U.; U. A. Birnin-Yauri; C. Muhammad and A. Umar (2014). Assessment of some diary products sold in Sokoto Metropolis, Nigeria. International Journal of Advanced Research in Chemical Science, 1 (10): 31-37.

Saini, N.; A.K. Bhati; N. Singh; and F. C. Tuteja (2007). Trace mineral and vitamin $\mathrm{C}$ content of camel milk: a comparative study .Veterinary Practitioner, 8 (1): 20-21.

SAS. (2002). User's Guide: Statistics, Version 9.0 Edition. SAS Institute Inc., Cary, NC, USA.

Shamsia, S.M. (2009) Nutritional and therapeutic properties of camel and human milks International Journal of Genetics and Molecular Biology, 1 (2): 52-58.

Soliman, G. Z. A. ( 2005). Comparison Of Chemical And Mineral Content Of Milk From Human, Cow, Buffalo, Camel And Goat In Egypt. The Egyptian Journal of Hospital Medicine, 21: 116 130

WHO (1992). Cadmium. Environmental Health Criteria, vol- 134. World Health Organization, International Program on Chemical Safety (IPCS), Geneva, Switzerland.

WHO (2004). Lead exposure. In: Comparative quantification of health risks. Geneva, World Health Organization, pp. 1495-1542

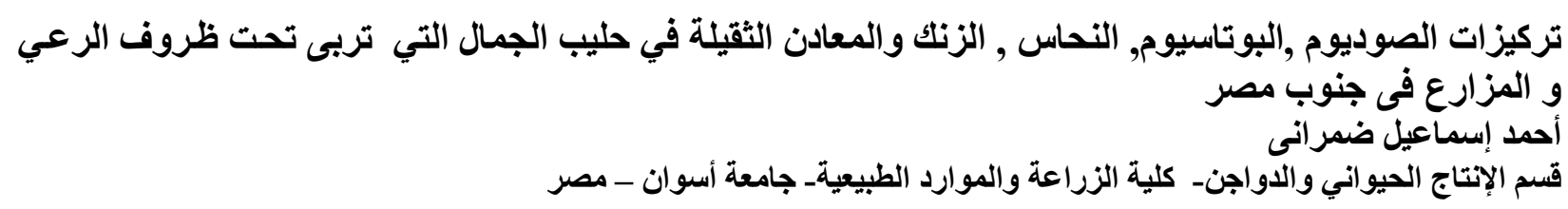

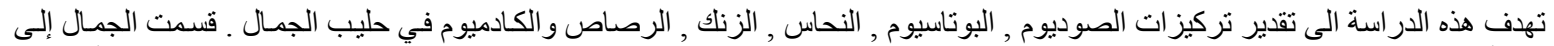

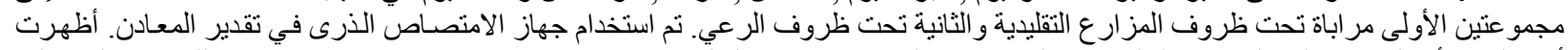

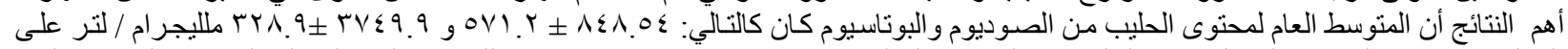

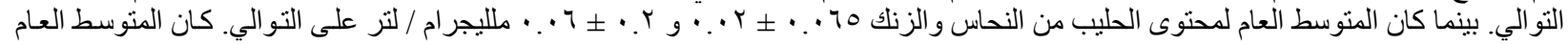

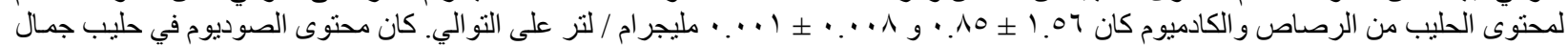

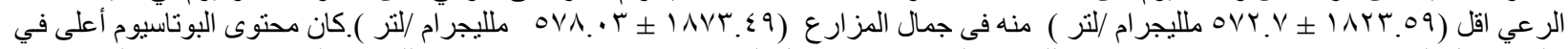

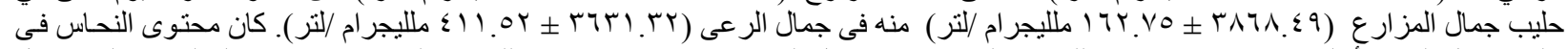

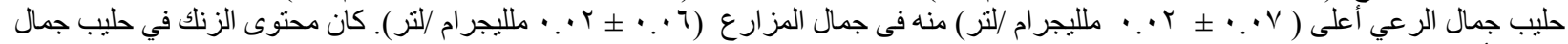

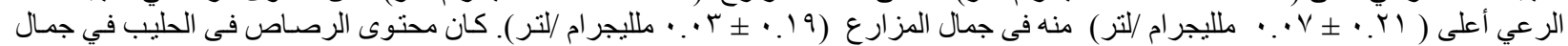

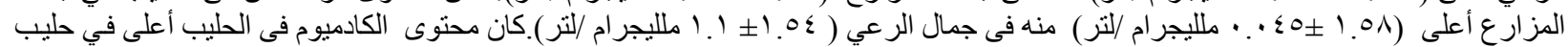

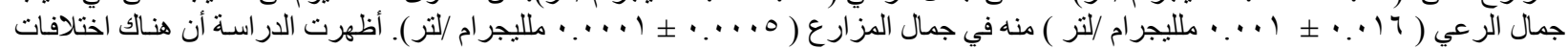

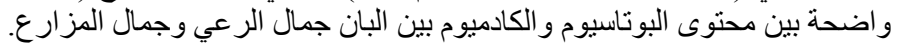

